
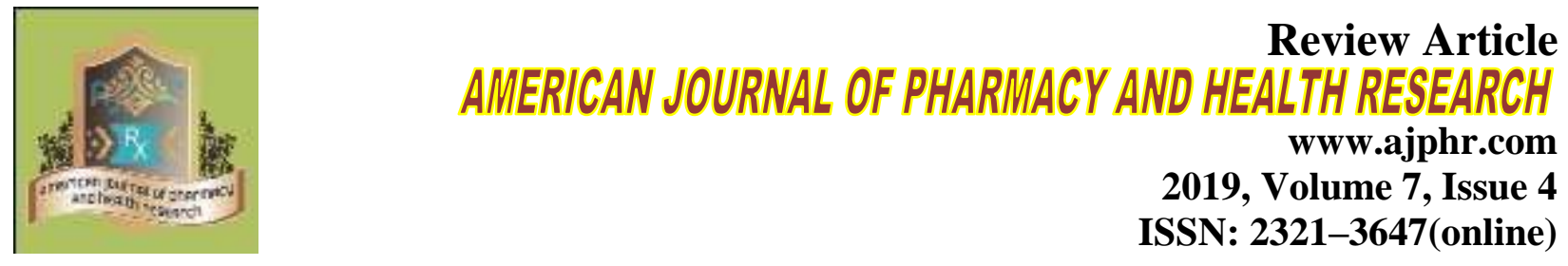

\title{
Biological Implications of Platelet-Rich Plasma Injection for The Treatment of Knee Osteoarthritis: A Review
}

\author{
A. Lachkar ${ }^{1}$, A. Najib ${ }^{\mathbf{1}}$, H. Yacoubi ${ }^{1}$ \\ 1 : Department of orthopedic surgery B - CHU Oujda University Mohamed first MOROCCO
}

\begin{abstract}
Osteoarthritis (OA) is a chronic musculoskeletal condition that commonly affects the knee and other joints. The disability associated with OA results in a considerable economic burden particularly joint replacement surgery and job-related loss of productivity. Until now, most cures research has focused on treatments to reduce pain and prevent functional decline. Analgesics and anti-inflammatory have short-term clinical benefits with some effect sizes which are generally small to moderate. Intra-articular therapies for OA (such as Hyaluronic Acid and corticosteroids) are also proposed but their benefits are limited to a few weeks. Platelet-rich plasma (PRP) injection into the affected joint is receiving increasing interest such as biologic therapy for OA. Current variability in the numerous PRP preparation and injection protocol in addition to considerable heterogeneity between studies make it difficult to establish recommendations regarding which type of PRP to use and for which indications. This manuscript will advance a systematic review of biological effect of PRP as a treatment for knee OA.
\end{abstract}

Keywords: Platelet-Rich Plasma - Biological implications - Injection Protocol - knee osteoarthritis

*Corresponding Author Email: dr.lachkar@gmail.com

Received 02 March 2019, Accepted 07 April2019

Please cite this article as: Lachkar A et al., Biological Implications Of Platelet-Rich Plasma Injection For The Treatment Of Knee Osteoarthritis: A Review. American Journal of Pharmacy \& Health Research 2019. 


\section{INTRODUCTION}

Osteoarthritis (OA) is a chronic musculoskeletal condition that commonly affects the knee and other joints. It is a major public health worldwide problem. The disability associated with OA results in a considerable economic burden particularly joint replacement surgery and job-related loss of productivity. Until now, most cures' research has focused on treatments to reduce pain and prevent functional decline. Analgesics and anti-inflammatory have short-term clinical benefits with some effect sizes which are generally small to moderate ${ }^{1}$. Intra-articular therapies for OA (such as Hyaluronic Acid and corticosteroids) are also proposed but their benefits are limited to a few weeks ${ }^{2}$. Platelet-rich plasma (PRP) injection into the affected joint is receiving increasing interest such as biologic therapy for OA. This article will advance a systematic review of biological effect of PRP as a treatment for knee OA.

\section{Biological Mechanisms Of PRP In The Context Of OA:}

Recent progress in molecular biology has supplied new understandings regarding OA physiopathology in which growth factors, inflammatory mediators, chondrocyte apoptosis and imbalance between catabolic and anabolic mechanisms plays an important role. Several cytokines such as transforming growth factor $\beta$, interleukin-1 $\beta$, nitric oxide synthetase and proteases all appear to be required for cartilage destruction in the pathogenesis of $\mathrm{OA}^{3}$. PRP is an autologous blood product that contains an elevated concentration of platelets above that of whole blood; it may be beneficial in OA by interfering with inflammatory and catabolic events. Activation of PRP releases a sustained release of biologically active growth factors, plateletderived growth factor, transforming growth factor- $\beta$, type I insulin-like growth factor and vascular endothelial growth factor ${ }^{4}$. These proteins are responsible for chondrocyte apoptosis inhibition, bone and vessel remodeling, inflammatory modulation and collagen synthesis ${ }^{4,5}$. Preclinical literature supports the use of PRP injections to regenerate damaged joint tissue in OA. In vitro studies show a direct effect of PRP on cartilage with increases in chondrocyte proliferation and enhanced production of proteoglycans and type II collagen ${ }^{6-8}$; it also provides positive effects on meniscal cells ${ }^{9}$ and synoviocytes ${ }^{10}$. Research suggests also a direct analgesic effect via augmentation of cannabinoid receptors ${ }^{11}$.

\section{Methods of Preparation of Prp and Injection Protocol:}

There is a wide variation in the reported protocols for standardization and preparation of PRP (table 1); this reflects the lack of evidence supporting one particular protocol over another. Most studies in knee OA have administered PRP injections weekly. One to four PRP injections have 
been used with the most common being three injections; injection volumes have ranged from 3 to $8 \mathrm{~mL}$. Different activating agents have been described; most studies have used calcium to activate platelets although some authors do not activate platelets prior to injection. One of the most variable aspects of the PRP preparation technique is the centrifugation protocol. Studies used single or double-spin technique with inconsistent spin speed and times. The studies that have used a single-spin technique with spin speeds around 1500rpm and spin times around 8min report a leukocyte-poor PRP (LP-PRP) by excluding leukocytes and neutrophils in particular; those ones that have used a double-spinning approach with spin speeds and times of up to 3400rpm and 15min for the second spin report a leukocyte-rich PRP (LR-PRP) product ${ }^{12-27}$. While some believe that superior outcomes are obtained with LP-PRP because of deleterious effects of proteases and reactive oxygen species released from white cells, others think that leukocytes are an important origin of enzymes and cytokines which may be important for infections ${ }^{28,29}$. However, more adverse events were described by patients who received the LRPRP product ${ }^{30}$. Recently, a classification system of PRP protocol was proposed by DeLong et al. $^{31}$; it is based on three components: (1) the absolute number of platelets, (2) the manner in which platelet activation occurs, and (3) the presence or absence of white cells. 
Table 1: PRP preparation and injection protocols

\begin{tabular}{|c|c|c|c|c|c|c|}
\hline Author & $\begin{array}{l}\text { Centrifugation } \\
\text { Protocol }\end{array}$ & $\begin{array}{l}\text { Leukocyte } \\
\text { Rich/poor }\end{array}$ & \begin{tabular}{|l|} 
Injection \\
Frequency
\end{tabular} & $\begin{array}{l}\text { Injection } \\
\text { Approach }\end{array}$ & $\begin{array}{l}\text { Injection } \\
\text { Count }\end{array}$ & $\begin{array}{l}\text { Volume } \\
\text { Injected }(\mathrm{ml})\end{array}$ \\
\hline Filardo et al. [12] & $\begin{array}{l}\text { C1: } 1480 \mathrm{rpm} \text { for } 6 \mathrm{~min} \\
\mathrm{C} 2: 3400 \mathrm{rpm} \text { for } 15 \mathrm{~min}\end{array}$ & Rich & Weekly & Not reported & 3 & 5 \\
\hline Vaquerizo et al. [13] & $\mathrm{C} 1: 580 \mathrm{~g}$ for $8 \mathrm{~min}$ & Poor & Fortnightly & External Suprapatellar & 3 & 8 \\
\hline Raeissadat et al. [14] & $\begin{array}{l}\mathrm{C} 1: 1600 \mathrm{rpm} \text { for } 15 \mathrm{~min} \\
\mathrm{C} 2: 2800 \mathrm{rpm} \text { for } 7 \mathrm{~min}\end{array}$ & Rich & Four weekly & $\begin{array}{l}\text { Lateral midpatellar in extended } \\
\text { knee Position or anteromedial } \\
\text { In flexed knee position }\end{array}$ & 2 & 4 a 6 \\
\hline Angoorani et al. [15] & $\begin{array}{l}\text { C1 (women): } 1600 \mathrm{rpm} \text { for } 6 \mathrm{~min} \\
\text { C1 (men) } 1800 \mathrm{rpm} \text { for } 6 \mathrm{~min} \\
\text { C2: } 2000 \mathrm{rpm} \text { for } 5 \mathrm{~min}\end{array}$ & Not reported & Four weekly & Not reported & 2 & 5 \\
\hline Smith [16] & $\mathrm{C} 1: 1500 \mathrm{rpm}$ for $5 \mathrm{~min}$ & Poor & Weekly & Lateral Parapatellar & 3 & 3 a 8 \\
\hline $\begin{array}{l}\text { Simental-Mendia } \\
\text { et al. [17] }\end{array}$ & $\begin{array}{l}\text { C1: } 1800 \mathrm{rpm} \text { for } 10 \mathrm{~min} \\
\mathrm{C} 2: 3400 \mathrm{rpmfor} 12 \mathrm{~min}\end{array}$ & Poor & Fortnightly & Inferolateral & 3 & 3 \\
\hline Duymus et al. [18] & $\mathrm{C} 1: 3700 \mathrm{rpm}$ for $7 \mathrm{~min}$ & Not reported & 1 Month & Suprapatellar & 5 & 2 \\
\hline Battaglia et al. [19] & $\begin{array}{l}\text { C1: } 1800 \mathrm{rpm} \text { for } 15 \mathrm{~min} \\
\mathrm{C} 2: 3500 \mathrm{rpm} \text { for } 10 \mathrm{~min}\end{array}$ & Not reported & Fortnightly & Lateromedial and caudocranial & 5 & 3 \\
\hline Di Sante et al. [20] & $\begin{array}{l}\mathrm{C} 1: 3100 \mathrm{rpm} \text { for } 9 \mathrm{~min} \\
\mathrm{C} 2: 3100 \mathrm{rpm} \text { for } 9 \mathrm{~min}\end{array}$ & Not reported & Weekly & Not reported & 3 & 3 \\
\hline Cerza et al. [21] & Single & Poor & Weekly & Superolateral & 4 & 5,5 \\
\hline Sanchez et al. [22] & $\mathrm{C} 1: 580 \mathrm{~g}$ for $8 \mathrm{~min}$ & Poor & Weekly & Not reported & 3 & 8 \\
\hline Patel et al. [23] & $\mathrm{C} 1: 1500 \mathrm{rpm}$ for $15 \mathrm{~min}$ & Poor & 3 weekly & Supralateral & 1 vs 2 prp & 8 \\
\hline Gormelli et al. [24] & $\begin{array}{l}\mathrm{C} 1: 1500 \mathrm{rpm} \text { for } 6 \mathrm{~min} \\
\mathrm{C} 2: 3500 \mathrm{rpm} \text { for } 12 \mathrm{~min}\end{array}$ & Not reported & Weekly & Superolateral & 3 vs 1 & 5 \\
\hline Lana et al. [25] & $\begin{array}{l}\mathrm{C} 1: 300 \mathrm{~g} \text { for } 5 \mathrm{~min} \\
\mathrm{C} 2: 700 \mathrm{~g} \text { for } 17 \mathrm{~min}\end{array}$ & Not reported & Fortnightly & $\begin{array}{l}\text { Lateral } \\
\text { Midpatellar }\end{array}$ & 3 & 5 \\
\hline Paterson et al. [26] & $\begin{array}{l}\mathrm{C} 1: 2000 \mathrm{rpm} \text { for } 5 \mathrm{~min} \\
\mathrm{C} 2: 3000 \mathrm{rpm} \text { for } 3 \mathrm{~min}\end{array}$ & Not reported & Weekly & Anteromedial & 3 & 5 \\
\hline Dallari et al. [27] & $\begin{array}{l}\text { C1: } 1400 \mathrm{rpm} \text { for } 6 \mathrm{~min} \\
\mathrm{C} 2: 3400 \mathrm{rpm} \text { for } 15 \mathrm{~min}\end{array}$ & Not reported & Weekly & $\begin{array}{l}\text { Lateromedial and } \\
\text { caudocranial }\end{array}$ & 3 & 5 \\
\hline
\end{tabular}




\section{Outcomes and Clinical Implications:}

At 6 months following three PRP injections Sampson et al. ${ }^{32}$ reported that $50 \%$ of their patients with knee OA showed greater cartilage volume at the intercondylar notch and femoral condyles using ultrasonogrphy to quantify knee cartilage. In his uncontrolled study involving 15 patients with no or early knee OA and received a single PRP injection, Halpern ${ }^{33}$ found there are no significant structural changes at 12-month follow-up assessed using magnetic resonance imaging. However, given the lack of high-quality studies, no clinical guidelines can be made at this time to recommend for or against the use of PRP for the management of knee OA ${ }^{34-36}$.

\section{CONCLUSION:}

The safety and simplicity of PRP injection appears to be an effective solution for symptomatic OA knees; it can also be an interesting and promising option for both clinicians and patients with significant reduction in pain and improvement in knee function after treatment. Current variability in the numerous PRP preparation and injection protocol in addition to considerable heterogeneity between studies make it difficult to establish recommendations regarding which type of PRP to use and for which indications.

\section{REFERENCES:}

1. Zhang W, Nuki G, Moskowitz RW, Abramson S, Altman RD, Arden NK, et al. OARSI recommendations for the management of hip and knee osteoarthritis: part III: changes in evidence following systematic cumulative update of research published through January 2009. Osteoarth Cart. 2010;18:476-99. doi:10.1136/ard. 2009.113100.

2. McAlindon TE, Bannuru RR, Sullivan MC, Arden NK, Berenbaum F, Bierma-Zeinstra $\mathrm{SM}$, et al. OARSI guidelines for the nonsurgical management of knee osteoarthritis. Osteoarthr Cartil. 2014;22:363-88. doi:10.1016/j.joca.2014.01.003.

3. Berenbaum F. Osteoarthritis as an inflammatory disease (osteoarthritis is not osteoarthrosis!). Osteoarth Cart. 2013;21:16-21. doi: 10.1016/j.joca.2012.11.012.

4. Sundman EA, Cole BJ, Karas V, Della Valle C, Tetreault MW, Mohammed HO, et al. The antiinflammatory and matrix restorative mechanisms of platelet-rich plasma in osteoarthritis. Am J Sports Med. 2013; doi:10.1177/0363546513507766.

5. Drengk A, Zapf A, Sturmer EK, Sturmer KM, Frosch K-H. Influence of platelet-rich plasma on chondrogenic differentiation and proliferation of chondrocytes and mesenchymal stem cells. Cells Tissues Organs. 2008;189:317-26. 
6. Muraglia A, Ottonello C, Spano R, Dozin B, Strada P, Grandizio M, et al. Biological activity of a standardized freeze-dried platelet derivative to be used as cell culture medium supplement. Platelets. 2014;25:211-20. doi:10.3109/09537104.2013.803529.

7. Wu CC, Chen WH, Zao B, Lai PL, Lin TC, Lo HY, et al. Regenerative potentials of platelet-rich plasma enhanced by collagen in retrieving pro-inflammatory cytokineinhibited chondrogenesis. Biomaterials. 2011;32:5847-54. doi:10.1016/j.biomaterials.2011.05.002.

8. Akeda K, An HS, Okuma M, Attawia M, Miyamoto K, Thonar EJMA, et al. Platelet-rich plasma stimulates porcine articular chondrocyte proliferation and matrix biosynthesis. Osteoarth Cart. 2006;14:1272-80. doi:10.1016/j.joca.2006.05.008.18.

9. Ishida K, Kuroda R, Miwa M, Tabata Y, Hokugo A, Kawamoto T, et al. The regenerative effects of platelet-rich plasma on meniscal cells in vitro and its in vivo application with biodegradable gelatin hydrogel. Tissue Eng. 2007;13:1103-12. doi:10.1089/ten.2006.0193.

10. Anitua E, Sanche M, Nurden AT, Zalduendo MM, de la Fuente M, Azofra J, et al. Plateletreleased growth factors enhance the secretion of hyaluronic acid and induce hepatocyte growth factor production by synovial fibroblasts from arthritic patients. Rheumatology (Oxford). 2007;46:1769-72. doi:10.1093/rheumatology/kem234.

11. Lee HR, Park KM, Joung YK, Park KD, Do SH. Platelet-rich plasma loaded hydrogel scaffold enhances chondrogenic differentiation and maturation with up-regulation of CB1 and CB2. J Control Release. 2012;159:332-7. doi:10.1016/j.jconrel.2012.02.008.

12. Filardo G, Kon E, Di Martino A, Di Matteo B, Merli M, Cenacchi A, et al. Platelet-rich plasma vs hyaluronic acid to treat knee degenerative pathology: study design and preliminary results of a randomized controlled trial. BMC Musculoskelet Disord. 2012a;13: 229. doi:10.1186/1471-2474-13- 229.

13. Vaquerizo V, Plasencia MA, Arribas I, Seijas R, Padilla S, Orive G et al. Comparison of intraarticular injections of plasma rich in growth factors (PRGF-Endoret) versus Durolane hyaluronic acid in the treatment of patients with symptomatic osteoarthritis: a randomized controlled trial. Arthroscopy. 2013;29:1635-43. doi:10.1016/j.arthro.2013.07.264.

14. Raeissadat SA, Rayegani SM, Hassanabadi H, Fathi M, Ghorbani E, Babaee M, et al. Knee osteoarthritis injection choices: plateletrich plasma (PRP) versus hyaluronic acid (a 
one-year randomized clinical trial). Clin Med Insights Arthritis Musculoskelet Disord. 2015;8:1-8. doi:10.4137/CMAMD.S17894.

15. Angoorani H, Mazaherinezhad A, Marjomaki O, Younespour S. Treatment of knee osteoarthritis with platelet-rich plasma in comparison with transcutaneous electrical nerve stimulation plus exercise: a randomized clinical trial. Med J Islam Repub Iran. 2015;29:223.

16. Smith PA. Intra-articular autologous conditioned plasma injections provide safe and efficacious treatment for knee osteoarthritis: an FDA-sanctioned, randomized, doubleblind, placebo controlled clinical trial. Am J Sports Med. 2016;44:884-91. doi:10.1177/0363546515624678.

17. Simental-Mendia M, Vilchez-Cavazos JF, Pena-Martinez VM, Said-Fernandez S, LaraArias J, Martinez-Rodriguez HG. Leukocyte-poor platelet-rich plasma is more effective than the conventional therapy with acetaminophen for the treatment of early knee osteoarthritis. Arch Orthop Trauma Surg. 2016;136:1723-32. doi:10.1007/s00402-0162545-2.

18. Duymus TM,Mutlu S, Dernek B, Komur B, Aydogmus S, Kesiktas FN. Choice of intraarticular injection in treatment of knee osteoarthritis: platelet-rich plasma, hyaluronic acid or ozone options. Knee Surg Sports Traumatol Arthrosc. 2016; doi:10.1007/s00167-0164110-5.

19. Battaglia M, Guaraldi F, Vannini F, Rossi G, Timoncini A, Buda R, et al. Efficacy of ultrasoundguided intra-articular injections of platelet-rich plasma versus hyaluronic acid for hip osteoarthritis. Orthopedics. 2013;36:e1501-8.

20. Di Sante L, Villani C, Santilli V, Valeo M, Bologna E, Imparato L, et al. Intra-articular hyaluronic acid VS platelet-rich plasma in the treatment of hip osteoarthritis. Med Ultrason. 2016;18:463-8. doi:10.11152/mu-874.

21. Cerza F, Carni S, Carcangiu A, Di Vavo I, Schiavilla V, Pecora A, et al. Comparison between hyaluronic acid and platelet-rich plasma, intra-articular infiltration in the treatment of gonarthrosis. Am J Sports Med. 2012;40:2822-7. doi:10.1177/0363546512461902.

22. Sanchez M, Fiz N, Azofra J, Usabiaga J, Aduriz Recalde E, Garcia Gutierrez A, et al. A randomized clinical trial evaluating plasma rich in growth factors (PRGF-Endoret) versus hyaluronic acid in the short-term treatment of symptomatic knee osteoarthritis. Arthroscopy. 2012;28:1070-8. doi:10.1016/j.arthro.2012.05.011. 
23. Patel S, Dhillon MS, Aggarwal S, Marwaha N, Jain A. Treatment with platelet-rich plasma is more effective than placebo for knee osteoarthritis: a prospective, double-blind, randomized trial. Am J Sports Med. 2013;41:356-64. doi:10.1177/0363546512471299.

24. Gormeli G, Gormeli CA, Ataoglu B, Colak C, Aslanturk O, Ertem K. Multiple PRP injections are more effective than single injections and hyaluronic acid in knees with early osteoarthritis: a randomized, double-blind, placebo-controlled trial. Knee Surg Sports Traumatol Arthrosc. 2015; doi:10.1007/s00167-015-3705-6.

25. Lana JF, Weglein A, Sampson SE, Vicente EF, Huber SC, Souza CV, et al. Randomized controlled trial comparing hyaluronic acid, platelet-rich plasma and the combination of both in the treatment of mild and moderate osteoarthritis of the knee. J Stem Cells Regen Med. 2016;12:69-78.

26. Paterson KL, Nicholls M, Bennell KL, Bates D. Intra-articular injection of photoactivated platelet-rich plasma in patients with knee osteoarthritis: a double-blind, randomized controlled pilot study. BMC Musculoskelet Disord. 2016;17:67. doi:10.1186/s12891-016-0920-3.

27. Dallari D, Stagni C, Rani N, Sabbioni G, Pelotti P, Torricelli P, et al. Ultrasound-guided injection of platelet-rich plasma and hyaluronic acid, separately and in combination, for hip osteoarthritis: a randomized controlled study. Am J SportsMed. 2016;44:664-71. doi:10.1177/0363546515620383.

28. Filardo G, Kon E, Pereira Ruiz MT, Vaccaro F, Guitaldi R, Di Martino A, et al. Plateletrich plasma intra-articular injections for cartilage degeneration and osteoarthritis: singleversus double spinning approach. Knee Surg Sports Traumatol Arthrosc. 2012b;20:208291. doi:10.1007/s00167-011-1837-x.

29. Riboh JC, Saltzman BM, Yanke AB, Fortier L, Cole BJ. Effect of leukocyte concentration on the efficacy of platelet-rich plasma in the treatment of knee osteoarthritis. Am J Sports Med. 2016;44:792-800. doi:10.1177/0363546515580787.

30. Braun HJ, Kim HJ, Chu CR, Dragoo JL. The effect of platelet-rich plasma formulations and blood products on human synoviocytes: implications for intra-articular injury and therapy. Am J Sports Med. 2014;42:1204-10. doi:10.1177/0363546514525593.

31. DeLong JM, Russell RP, Mazzocca AD. Platelet-rich plasma: the PAW classification system. Arthroscopy. 2012;28:998-1009. doi:10.1016/j.arthro.2012.04.148. 
32. Sampson S, Reed M, Silvers H,MengM, Mandelbaum B. Injection of platelet-rich plasma in patients with primary and secondary knee osteoarthritis: a pilot study. Am J Phys Med Rehabil. 2010;89:961-9. doi:10.1097/PHM.0b013e3181fc7edf.

33. Halpern B, Chaudhury S, Rodeo SA, Hayter C, Bogner E, Potter HG, et al. Clinical and MRI outcomes after platelet-rich plasma treatment for knee osteoarthritis. Clin J Sport Med. 2013;23:238-9. doi:10.1097/JSM.0b013e31827c3846.

34. National Institute for Health and Care Excellence (UK). Osteoarthritis: Care and Management in Adults. National Clinical Guideline Centre (UK). Clinical Guidelines No. 177. 2014; Feb.

35. Hochberg MC, Altman RD, Toupin April K, Benkhalti M, Guyatt G, McGowan J, et al. American College of Rheumatology 2012 recommendations for the use of nonpharmacologic and pharmacologic therapies in osteoarthritis of the hand, hip, and knee. Arthritis Care Res. 2012;64:465-74. doi:10.1002/acr.21596.

36. Jevsevar DS. Treatment of Osteoarthritis of the Knee: Evidence-Based Guideline. Journal of the American Academy of Orthopaedic Surgeons. 2013;21(9):571-576. doi: 10.5435/JAAOS-21-09-571. 